\title{
Correction to: Statistical filtering of useful concrete creep data from imperfect laboratory tests
}

\author{
Mohammad Rasoolinejad · Saeed Rahimi-Aghdam • Zdeněk P. Bažant
}

Published online: 27 March 2019

(C) RILEM 2019

Correction to: Materials and Structures (2018) 51:153
https://doi.org/10.1617/s11527-018-1278-9

The article Statistical filtering of useful concrete creep data from imperfect laboratory tests, written by Mohammad Rasoolinejad, Saeed Rahimi-Aghdam, Zdenek P. Bazant, was originally published online without Open Access. After publication in volume 51, article ID 153 RILEM decided to grant the author to opt for open choice and to make the article an openaccess publication. Therefore, the copyright of the article has been changed to (C) The Author(s) 2018 and the article is forthwith distributed under the terms of the Creative Commons Attribution 4.0 International License (http://creativecommons.org/licenses/by/4.0/ ), which permits use, duplication, adaptation, distribution and reproduction in any medium or format, as long as you give appropriate credit to the original author(s) and the source, provide a link to the Creative Commons license and indicate if changes were made.

Publisher's Note Springer Nature remains neutral with regard to jurisdictional claims in published maps and institutional affiliations.
The original article can be found online at https://doi.org/10.1617/s11527-018-1278-9.

M. Rasoolinejad · S. Rahimi-Aghdam Northwestern University, Evanston, IL, USA

\section{Z. P. Bažant ( $\square)$}

Civil and Mechanical Engineering and Materials Science, Northwestern University, 2145 Sheridan Road, CEE/

A135, Evanston 60208, IL, USA

e-mail: z-bazant@northwestern.edu 